\title{
Growing Poplar in Acid Soils: Biomass Yield and Ash Behavior
}

\author{
Cristina Eimil-Fraga ${ }^{1,+}$, Nerea Oliveira ${ }^{2, *,+}+\mathbb{C}$, Luis Ortíz-Torres ${ }^{3}$, Juan Luis Rodríguez-Somoza ${ }^{3}$ \\ and Roque Rodríguez-Soalleiro ${ }^{1}$
}

1 Sustainable Forest Management Unit, University of Santiago de Compostela, 27002 Lugo, Spain; cristina.eimil@usc.es (C.E.-F.); roque.rodriguez@usc.es (R.R.-S.)

2 Forest Research Center, National Institute for Agricultural and Food Research and Technology (INIA-CSIC), 28040 Madrid, Spain

3 Forest Biomass Research Group, A Xunqueira Campus, Forest Engineering School, University of Vigo, 36005 Pontevedra, Spain; lortiz@uvigo.es (L.O.-T.); jlsomoza@uvigo.es (J.L.R.-S.)

* Correspondence: oliveira.nerea@inia.es

+ These authors contributed equally to this paper.

check for updates

Citation: Eimil-Fraga, C.; Oliveira, N.; Ortíz-Torres, L.; RodríguezSomoza, J.L.; Rodríguez-Soalleiro, R. Growing Poplar in Acid Soils: Biomass Yield and Ash Behavior. Forests 2021, 12, 960. https:/ / doi.org/10.3390/f12070960

Academic Editor: Philip G. Comeau

Received: 4 June 2021

Accepted: 15 July 2021

Published: 20 July 2021

Publisher's Note: MDPI stays neutral with regard to jurisdictional claims in published maps and institutional affiliations.

Copyright: (c) 2021 by the authors. Licensee MDPI, Basel, Switzerland. This article is an open access article distributed under the terms and conditions of the Creative Commons Attribution (CC BY) license (https:// creativecommons.org/licenses/by/ $4.0 /)$.
Abstract: Atlantic areas of southern Europe have low water restrictions but are also characterized by acid soils with low intrinsic fertility, so the selection of clones that have adapted to these characteristics is essential. In this study, biomass yield data for eight poplar clones established in two trials were evaluated after the first rotation. Both sites were representative of acid soils that had previously been used for agriculture and had low levels of alkali and alkaline earth elements. The first trial was used to determine which clones performed the best in terms of biomass and stem size, testing two Populus $\times$ euramericana (Dode) Guinier (I-214 and AF2), two $P . \times$ interamericana Van Brokehuizen $\times$ P. nigra L. (Monviso, AF6), three P. $\times$ interamericana (Unal, Beaupre and Raspalje), and one P. trichocarpa Torr \& A. Gray (Trichobel) clone. The second trial explored the possibility of simultaneously growing biomass and timber, specifically considering the Raspalje and Trichobel balsam poplar clones. To complete a previous study on energy properties, nine biomass samples were obtained from each of the eight clones to evaluate the composition and behavior of the ash generated during combustion, particularly the sintering risk. Several indices of sintering risk were explored and compared with the actual sintering using the BioSlag test. The results show large differences in biomass yield between clones, with the balsam poplar derived clones (both hybrid or pure Populus trichocarpa) performing the best. Growth results for stems planted for wood and the cuttings planted in between these stems show that a mixed biomass-timber arrangement provides good results, at least during the first rotation. The relative proportion of oxides in the poplar ash followed the order $\mathrm{CaO}>\mathrm{K}_{2} \mathrm{O}>\mathrm{MgO}>>\mathrm{P}_{2} \mathrm{O}_{5}>>\mathrm{SiO}_{2}>\mathrm{Al}_{2} \mathrm{O}_{3}>\mathrm{Na}_{2} \mathrm{O}>\mathrm{Fe}_{2} \mathrm{O}_{5}>>\mathrm{TiO}_{2}$. Significant differences between clones were found for $\mathrm{K}_{2} \mathrm{O}$ and $\mathrm{MgO}$. Risk indices showed moderate levels of sintering derived from alkali elements, with significant differences between clones. The actual slagging and the hardness of the slag particles were very low thus, denoting good ash behavior during combustion, particularly for the clones selected for biomass yield. No significant covariate effect of basal diameter was found for any of the analyzed variables. We conclude that growing site-undemanding poplar clones in acid soils can yield both reasonable levels of biomass yield and good quality chips for combustion in domestic thermal systems.

Keywords: biomass yield in acid soils; poplar ash composition; poplar ash slagging

\section{Introduction}

The need for a better characterization of biomass for its final use (either as bioenergy or bioproducts) has been pointed out in several reviews of poplar short rotation coppice (SRC) plantations [1-3]. Such improvements should be coupled with genotype testing in a range of environments to increase biomass production, which would also ensure good quality biomass for generating bioproducts and bioenergy for different applications (heat, electricity, and second-generation biofuels) [3]. 
Analysis of several energy properties of poplar grown in acid soils has shown the combined effects of size (basal diameter) and clone on variables such as ash content, $\mathrm{N}$ content, high heating value, and the net heating value [4]. The authors of the study concluded that several clones, particularly when grown at densities and rotations able to reach large enough basal diameters $(>60 \mathrm{~mm})$ with a low proportion of branches in the biomass, could directly provide chips of A2 quality according to European standards for non-industrial applications [4]. In particular, this was found for the poplar clones Trichobel, Raspalje, Beaupre, and Unal, derived from Populus trichocarpa, Torr \& A. Gray (a balsam poplar included in the Tacamahaca section), and the hybrid group Populus $\times$ interamericana Van Brokehuizen (P. trichocarpa $\times$ P. deltoides Bartr. ex Marsh.). Balsam poplars and their hybrids have been tested in suboptimal conditions in Spain, having shown their ability to grow in soils of moderate fertility (see Table 3 in Oliveira, et al. [1]).

Ash content and behavior during combustion are particularly important in regard to biomass fuels [5]. The main complications of using wood chips or pellets as biofuels, particularly in domestic boilers, are the slagging and fouling risks, which can cause damage and limit the combustion efficiency of the boilers [6]. Woody biomass is known to contain low amounts of $\mathrm{Si}$, but high amounts of alkali and alkaline-earth components, particularly in short rotation coppice grown in fertile soils. Although growing site-undemanding poplar clones in acid soils have shown some potential to produce low-ash biomass [4], the ash behavior has not yet been evaluated.

Little research has been conducted regarding the sintering and fouling risk of SRC poplar biomass and its variations in relation to the clones and the stem sizes. The work of Monedero, et al. [7] applied two indices, i.e., the ratio between alkaline metal oxides and silica $\left(\mathrm{K}_{2} \mathrm{O}+\mathrm{Na}_{2} \mathrm{O} / \mathrm{SiO}_{2}\right)$ and the ratio between alkaline metal oxides and the higher heating value (alkali index), to 10 clones and predicted a low risk of fouling, although no experimental evidence was provided. Recently, two indices characterizing the experimental tendency for bed agglomeration have been evaluated: the Bioslag test and the hardness index [8,9]. These indices are based on the granulometry and hardness of the ash deposits obtained by complete combustion [10]. The slagging level has been shown to be related to wood-derived fuels with a high inherent silicon content or that are contaminated with sand material [11].

The aim of the present study was to evaluate the growth of eight poplar clones grown for biomass production in acid soils in Atlantic Spain. Additional objectives were to evaluate the ash composition and properties and to provide experimental evidence of fouling and sintering for a range of sizes of these poplar clones. Our initial hypothesis was that the presence of a genotype effect and a diameter covariate will affect sintering risk indices and the actual sintering of the ash.

\section{Materials and Methods}

\subsection{Study Sites}

The samples used for the energy properties evaluation were obtained in two trials established in Bóveda, Lugo, Spain (coordinates $42^{\circ} 36^{\prime} 30.50^{\prime \prime} \mathrm{N}$ and $7^{\circ} 28^{\prime} 12.72^{\prime \prime} \mathrm{W}$ ), at an elevation $365 \mathrm{~m}$, in a transition area between Atlantic and Mediterranean climates. The first trial was established in a double row layout, with a density of 10,600 cuttings ha ${ }^{-1}$. Eight poplar clones were grown in the first trial: two $P . \times$ euramericana (Dode) Guinier (I-214 and AF2), two $P . \times$ interamericana $\times$ P. nigra L. (Monviso and AF6), three $P . \times$ interamericana (Unal, Beaupre and Raspalje), and one P. trichocarpa (Trichobel) clone. Biomass yield was recorded after an initial rotation of 4 years.

The second trial was established after evaluation of the first rotation yield in trial 1, focusing on the two productive clones of trial 1 that also yielded a low ash content (Trichobel and Raspalje), see Eimil-Fraga, et al. [4] for further details. The trial was established as a combined wood + biomass plantation in a single row layout and alternating with $6 \times 6 \mathrm{~m}$ stems of Raspalje planted for veneer, with an average density for the biomass rows 
of 6750 cuttings ha ${ }^{-1}$. Biomass was harvested at age 3 years. The arrangement and size of the experimental units are shown in Figure 1.
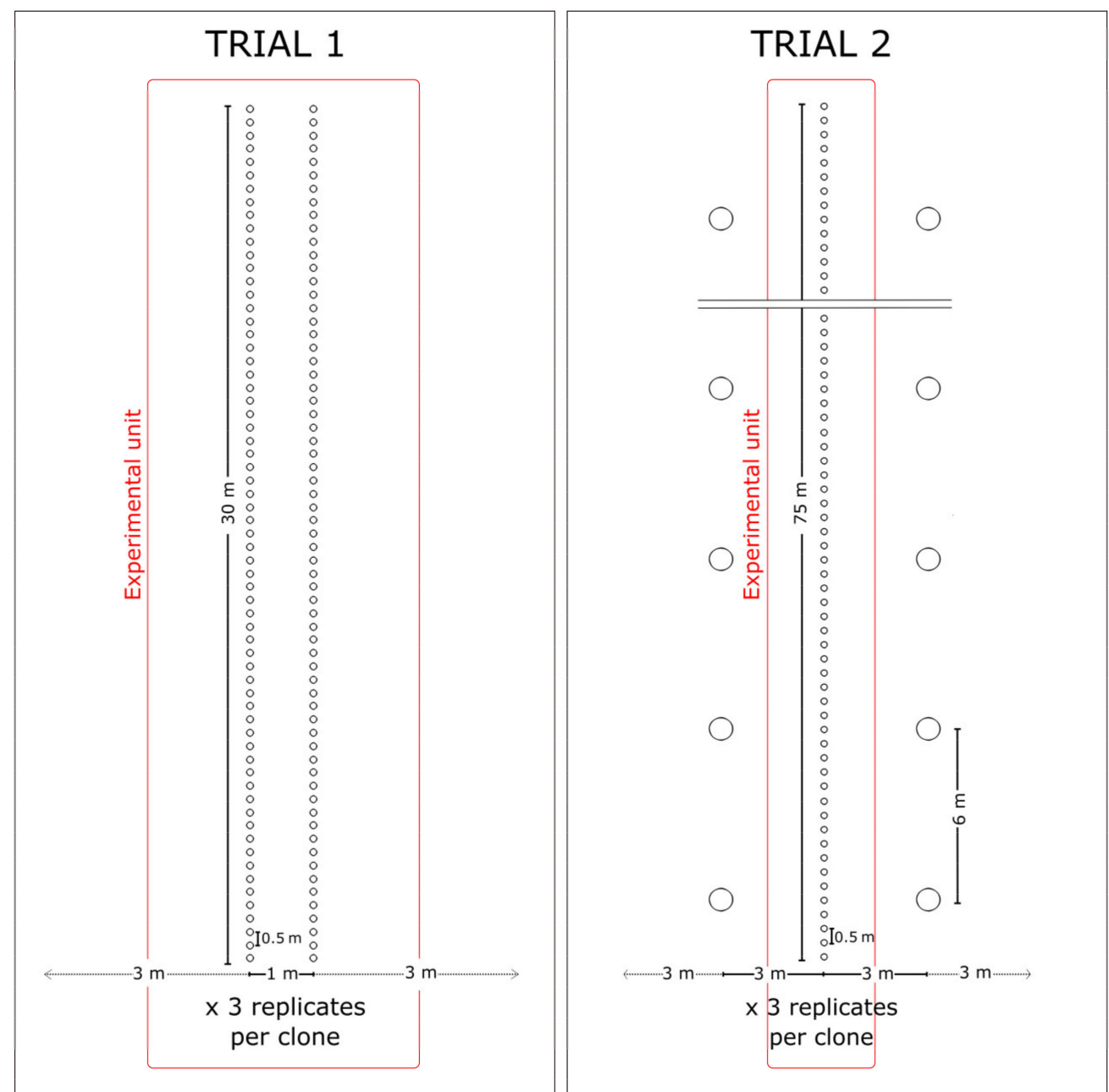

Figure 1. Layout of experimental units in trials 1 and 2. Each experimental unit had 3 replicates per clone.

The soil parameters obtained for the first $50 \mathrm{~cm}$ deep layer are shown in Table 1. Both sites have acid soils with a low effective cation exchange capacity (eCIC) and a moderate rate of exchange complex Al saturation. The soils were classified as Regosols and had an $\mathrm{AB}$ profile, characterized by an upper horizon depth of $50 \mathrm{~cm}$, rich in organic matter, and moderate levels of quartzite stoniness. The fertility was considered low for agricultural soils, with moderate concentrations of available $\mathrm{Ca}$ and $\mathrm{Mg}$ and low concentrations of $\mathrm{K}$ and $\mathrm{P}$.

Average rainfall in the area is $750 \mathrm{~mm}$ per year, with $155 \mathrm{~mm}$ occurring between May and September. Extensive crop management was applied, with irrigation applied during only the first summer after establishment. Mechanical weed control was applied twice a year. 
Table 1. Soil parameters of the study sites on the surface horizon of the soil $(0-50 \mathrm{~cm})$.

\begin{tabular}{ccc}
\hline Soil Parameter & Trial 1 & Trial 2 \\
\hline $\mathrm{pH}\left(\mathrm{H}_{2} \mathrm{O}\right)$ & 5.42 & 5.39 \\
$\mathrm{pH}(\mathrm{KCl})$ & 4.49 & 4.48 \\
$\mathrm{Ca}(\mathrm{cmol}(+) / \mathrm{kg})$ & 2.17 & 1.96 \\
$\mathrm{Mg}(\mathrm{cmol}(+) / \mathrm{kg})$ & 0.99 & 0.80 \\
$\mathrm{Na}(\mathrm{cmol}(+) / \mathrm{kg})$ & 0.07 & 0.07 \\
$\mathrm{~K}(\mathrm{cmol}(+) / \mathrm{kg})$ & 0.19 & 0.19 \\
$\mathrm{Al}(\mathrm{cmol}(+) / \mathrm{kg})$ & 1.30 & 0.50 \\
$\mathrm{CICe}(\mathrm{cmol}(+) / \mathrm{kg})$ & 4.72 & 3.51 \\
$\mathrm{Al} \mathrm{saturation}(\%)$ & 28.95 & 15.43 \\
$\mathrm{P}(\mathrm{mg} / \mathrm{kg})$ & 10.45 & 26.89 \\
$\mathrm{C}(\%)$ & 4.15 & 1.57 \\
$\mathrm{~N}(\%)$ & 0.29 & 0.13 \\
$\mathrm{C} / \mathrm{N}$ & 14.28 & 11.70 \\
Organic matter $(\%)$ & 7.15 & 2.79 \\
Texture & Loam & Clay-loam \\
\hline
\end{tabular}

Where eCIC is the effective cation exchange capacity.

\subsection{Evaluation of Yield Sampling and Slagging Risk Indices}

All of the trees were harvested to determine the biomass yield at 4 years of age. Both crops were in the first rotation, with roots that were the same age as the shoots. All of the dominant shoots in each stool were measured: basal diameter at a height of $10 \mathrm{~cm}\left(\mathrm{~d}_{10}, \mathrm{~cm}\right)$ to the nearest $\mathrm{mm}$ and total height $(\mathrm{h}, \mathrm{m})$ to the nearest $\mathrm{cm}$. After felling, the leaf-free fresh weight of all of the aboveground biomass components was determined, and samples were obtained for dry weight determination.

Standing trees planted for wood production were measured: breast height diameter $(\mathrm{d}$, $(\mathrm{cm})$ to the nearest $\mathrm{mm}$ ) and total height $(\mathrm{h}(\mathrm{m})$ to the nearest $\mathrm{cm}$ ) were measured using a caliper (Absolute, Vogel Germany, Kevelaer, Germany) and a hypsometer (Haglof's Vertex IV, Långsele, Sweden), respectively.

Samples were obtained from 9 trees per clone (only 6 samples for 3 of the clones), with the aim of covering the whole range of basal diameters and pooling data from both sites. The diameters ranged from 2.4 to $8.3 \mathrm{~cm}$ (mean, $5.4 \mathrm{~cm}$ ). Sample disks were taken from along the stem at relative heights of $0.25,0.5$, and $0.75 \mathrm{~m}$. Branches were also randomly sampled to ensure the same share was observed for fresh weight. The samples were transported to the laboratory where they were pooled and dried in a convection oven at $70{ }^{\circ} \mathrm{C}$ for $72 \mathrm{~h}$ to determine the dry weight. This allowed the average dry to fresh weight ratio to be calculated for each clone. The disks were then ground to $1 \mathrm{~mm}$ for the evaluation of the ash content, the chemical composition of ash, and slagging (three replicate samples).

The biomass ash was obtained through combustion at $550^{\circ} \mathrm{C}$ for a minimum of $5 \mathrm{~h}$ following UNE-EN ISO 18122 [12]. Ash samples were digested with nitric acid $\left(\mathrm{HNO}_{3}\right.$, $65 \%)$, hydrogen peroxide $\left(\mathrm{H}_{2} \mathrm{O}_{2}, 30 \%\right)$, and hydrofluoric acid $(\mathrm{HF}, 40 \%)$, using boric acid $\left(\mathrm{H}_{3} \mathrm{BO}_{3}, 4 \%\right)$ neutralization for the major elements. The digested samples were then analyzed using ICP-OES to determine $\mathrm{Si}, \mathrm{Al}, \mathrm{Ti}, \mathrm{Fe}, \mathrm{Na}, \mathrm{K}, \mathrm{Ca}, \mathrm{Mg}$, $\mathrm{P}$, and $\mathrm{S}$ following the UNE-EN ISO 16967 [13] standards for determining major elements in solid biofuels. $\mathrm{Cl}$ content was determined using X-ray fluorescence and applying the standards of UNE-EN ISO 16994 [14].

Four indeces were selected for predicting the sintering risk of poplar biomass, with the consideration that the feedstock is a $\mathrm{Ca}$ and $\mathrm{P}$ rich fuel type, according to previous studies $[8,15]$. The indeces listed in Table 2 were calculated on the basis of the ash oxide composition obtained at $550^{\circ} \mathrm{C}$ and considering the $\mathrm{HHV}$ average values per clone that were obtained in previous studies [4]. 
Table 2. Slagging indices calculated on the basis of ash composition at $550{ }^{\circ} \mathrm{C}$.

\begin{tabular}{cccc}
\hline Slagging Index & Explanation & Formulation & Reference \\
\hline $\mathrm{B}$ & Fraction of acid oxides in ash & $\left(\mathrm{Fe}_{2} \mathrm{O}_{3}+\mathrm{CaO}+\mathrm{MgO}+\mathrm{Na}_{2} \mathrm{O}+\mathrm{K}_{2} \mathrm{O}\right)$ ash $^{-1}$ & {$[16]$} \\
$\mathrm{A}\left(\mathrm{kg} \mathrm{GJ}^{-1}\right)$ & Alkali index & $\left(\mathrm{Na}_{2} \mathrm{O}+\mathrm{K}_{2} \mathrm{O}\right) \mathrm{A}(\%) / \mathrm{HHV}$ & {$[17]$} \\
$\mathrm{NaK} / \mathrm{B}$ & Alkali index modified & $\left(\mathrm{Na}_{2} \mathrm{O}+\mathrm{K}_{2} \mathrm{O}\right) /\left(\mathrm{Fe}_{2} \mathrm{O}_{3}+\mathrm{CaO}+\mathrm{MgO}+\mathrm{Na}_{2} \mathrm{O}+\mathrm{K}_{2} \mathrm{O}\right)$ & {$[8]$} \\
$\mathrm{SiP} / \mathrm{CaMg}$ & Empirical relationship & $\left(\mathrm{SiO}_{2}+\mathrm{P}_{2} \mathrm{O}_{5}\right) /(\mathrm{CaO}+\mathrm{MgO})$ & {$[8]$} \\
\hline
\end{tabular}

\subsection{Experimental Bed Agglomeration Indices}

Subsamples (100 to $200 \mathrm{~g}$ ) of each biomass were placed on a crucible and gradually heated in an oven (ThermConcept, KLS 03/10, Bremen, Germany) by applying a constant temperature ramp of $10{ }^{\circ} \mathrm{C}$ until reaching a temperature of $250{ }^{\circ} \mathrm{C}$, which was maintained for $4 \mathrm{~h}$ to eliminate all the volatile matter. Heating restarted with the same ramp until reaching a temperature of $1100{ }^{\circ} \mathrm{C}$, which was maintained at for $6 \mathrm{~h}$ by thermostatic regulation (Eurotherm 3500, Worthing, UK). The samples were then reweighed.

The ash samples were visually examined to determine the difficulty in separating the resulting ash particles from the crucible, considering three levels: weak sintering (WS, particles easily disaggregated), hard sintering (HS, particles difficult to break up), and completely melted (M, particles unable to be disaggregated). For the quantitative test (Bioslag), the procedure described by Vega-Nieva, et al. [8] and developed in the framework of the European project Domoheat was applied. The ash that was recovered after combustion was sieved using CISA RP-03 sieving equipment, a shaking frequency of $200 \mathrm{rpm}$, and a metal wire cloth sieve of a nominal aperture of $1 \mathrm{~mm}$. The Bioslag index was then calculated as the percentage of ash and slag particles $>1 \mathrm{~mm}$.

In addition, the hardness index (denoted HI) proposed by Rodríguez, et al. [9] and Rodríguez, et al. [10] was applied by considering the ratio of ash and slag $>1 \mathrm{~mm}$ at two power levels (P6 and P3) and by also applying a multiplicative coefficient of hardness (the coefficient equals 0.5 when the slag has a soft texture and 2 when it has a hard texture).

\subsection{Statistical Analysis}

Analysis of variance (ANOVA) was used to evaluate the effect of the clone on the growth and yield parameters and to assess yield differences between trials. Analysis of covariance (ANCOVA) was used to evaluate the effect of the clones on the energy properties of biomass, considering the basal diameter as a covariate. Several of the variables were transformed $(\arcsin \sqrt{x})$ to ensure that they were normally distributed, particularly those measured as percentages (oxide content in the ash). The generalized linear model procedure $(\mathrm{glm})$ was used to detect significant differences $(p<0.05)$ in order to address the unbalanced design. Tukey's test was used to compare the mean values. All analyses were performed using the R statistical package [18].

\section{Results and Discussion}

\subsection{Biomass Yield}

The biomass yield in trial 1 varied significantly $(p<0.001)$ between clones. Yield increased 4-fold from less productive clone (AF6) to the most productive one (Trichobel), as shown in Table 3. The clones were not equally ranked according to the average weight per stool and the yield because of high mortality rates after planting for AF6, AF2, and Monviso $(39.8 \%, 29.1 \%$, and $19.3 \%$, respectively) but much lower mortality rates for the other clones $(<5 \%)$. These large differences can be considered a consequence of the sprouting of cuttings and the performance of plants without irrigation. Evaluation of trial 1 clearly showed that the balsam poplars grow better in acid soils, with Trichobel, Beaupré, Unal, and Raspalje leading the group. 
Table 3. Size and dry matter biomass yield (with standard deviations) of different clones evaluated in trials 1 and 2 .

\begin{tabular}{|c|c|c|c|c|c|}
\hline Trial & Clone & $\begin{array}{c}\text { Basal Diameter } \\
(\mathrm{cm})\end{array}$ & $\begin{array}{c}\text { Total Height } \\
\text { (m) }\end{array}$ & $\begin{array}{c}\text { Biomass } \\
\left(\mathrm{kg} \mathrm{Tree}^{-1}\right)\end{array}$ & $\begin{array}{c}\text { Yield } \\
\left(\mathrm{Mg} \mathrm{ha}^{-1} \text { Year }^{-1}\right)\end{array}$ \\
\hline 1 & AF2 & $3.25 \mathrm{bc}(1.10)$ & $2.85 \mathrm{~cd}(0.66)$ & $0.70 \mathrm{~d}(0.69)$ & 1.65 b (0.77) \\
\hline 1 & AF6 & 2.79 c (1.23) & $2.58 \mathrm{~cd}(1.04)$ & $0.69 \mathrm{~d}(0.79)$ & $1.52 \mathrm{~b}(1.28)$ \\
\hline 1 & Beaupré & $3.88 \mathrm{ab}(1.21)$ & $3.42 \mathrm{ab}(0.88)$ & $1.44 \mathrm{~b}(0.91)$ & 4.39 a (1.48) \\
\hline 1 & $\mathrm{I}-214$ & 3.18 bc (1.07) & $3.11 \mathrm{c}(0.70)$ & $0.57 \mathrm{~d}(0.52)$ & $2.45 \mathrm{ab}(1.67)$ \\
\hline 1 & Monviso & 2.92 bc (1.04) & 2.97 c $(0.89)$ & $0.67 \mathrm{~d}(0.73)$ & $1.81 \mathrm{~b}(0.81)$ \\
\hline 1 & Unal & 4.09 a (1.18) & $4.02 \mathrm{a}(1.02)$ & $1.50 \mathrm{~b}(0.91)$ & 4.30 a (2.09) \\
\hline 1 & Raspalje & $3.60 \mathrm{ab}(1.08)$ & $3.54 \mathrm{ab}(0.90)$ & $1.22 \mathrm{ab}(0.88)$ & 3.81 a (1.24) \\
\hline 1 & Trichobel & $4.42 \mathrm{a}(1.32)$ & 4.46 a (1.29) & 2.36 a (1.67) & 6.37 a (3.51) \\
\hline 2 & Raspalje & 5.99 b (1.47) & $6.05 \mathrm{~b}(0.94)$ & $3.40 \mathrm{~b}(1.89)$ & $4.62(1.34)$ \\
\hline 2 & Trichobel & 6.45 a (1.30) & 6.76 a (1.11) & $4.10 \mathrm{a}(1.88)$ & $5.69(2.54)$ \\
\hline
\end{tabular}

Mean biomass productivity in trial $2\left(5.1 \mathrm{Mg} \mathrm{ha}^{-1}\right.$ year $\left.^{-1}\right)$ was significantly higher $(p<0.05)$ than for the same clones in trial $1\left(4.0 \mathrm{Mg} \mathrm{ha}^{-1}\right.$ year $\left.^{-1}\right)$, although the first rotation was shorter (3 years). The most productive clone in terms of biomass was again Trichobel, which performed significantly better in terms of basal diameter, total height, and average biomass per stool. The biomass yield of Trichobel was also higher, although not significantly, as there was a large variation between experimental units. Average mortality was $25 \%$, a rather high value attributed to the fact that irrigation was not applied after establishment.

Comparison of the two trials showed that the less dense arrangement of trial $2 \mathrm{fa}-$ vored the individual growth of each stool. In trial 2, both Raspalje and Trichobel almost exclusively had single stem stools, as was also observed in trial 1 for these clones. This resulted in much thicker shoots after three years than the overall values obtained for trial 1 , in which several of the tested clones already had double or triple stems in the first rotation.

Direct comparison of both trials should also consider the differences in terms of soil, as in trial 2, the $\mathrm{P}$ concentrations were higher and the $\mathrm{C} / \mathrm{N}$ ratio was lower, which can increase the availability of $\mathrm{N}$ and P. Moreover, trial 2 was established to test the simultaneous growth of the trees grown for biomass and timber. Along with the biomass yield obtained in trial 2, the growth the stems planted at $6 \times 6 \mathrm{~m}$ spacing over 4 years yielded a breast height diameter of $12.2 \mathrm{~cm}(\mathrm{sd}=2.1)$ and a height of $11.4 \mathrm{~m}(\mathrm{sd}=1.3)$.

Although the average production of irrigated SRC plantations under Mediterranean conditions in Spain is much higher $\left(15.3 \mathrm{Mg} \mathrm{ha}^{-1} \mathrm{yr}^{-1}\right.$ [19]) than obtained in the present study, the fact that irrigation is not necessary under Atlantic conditions is a strong advantage, both economically and ecologically. Numerous studies indicate the need for a shift in the Spanish SRC plantations towards a system with lower irrigation needs, even though this implies a decrease in production $[20,21]$. However, as seen in this case, some clones have responded better to these conditions, indicating that there is still some room for improvement with adequate clonal selection. This study shows how balsam poplar species and hybrids with $50 \%$ presence of these species responded better in terms of mortality and production. Figure 2 shows a comparison of the yield obtained for the clones yielding the best results for acid soils under Atlantic conditions (Trichobel, Raspalje, Beaupré, and Unal) (black) relative to the yield cited for said clones by Oliveira, et al. [1], both at the national level (green) and at the European level (blue). 


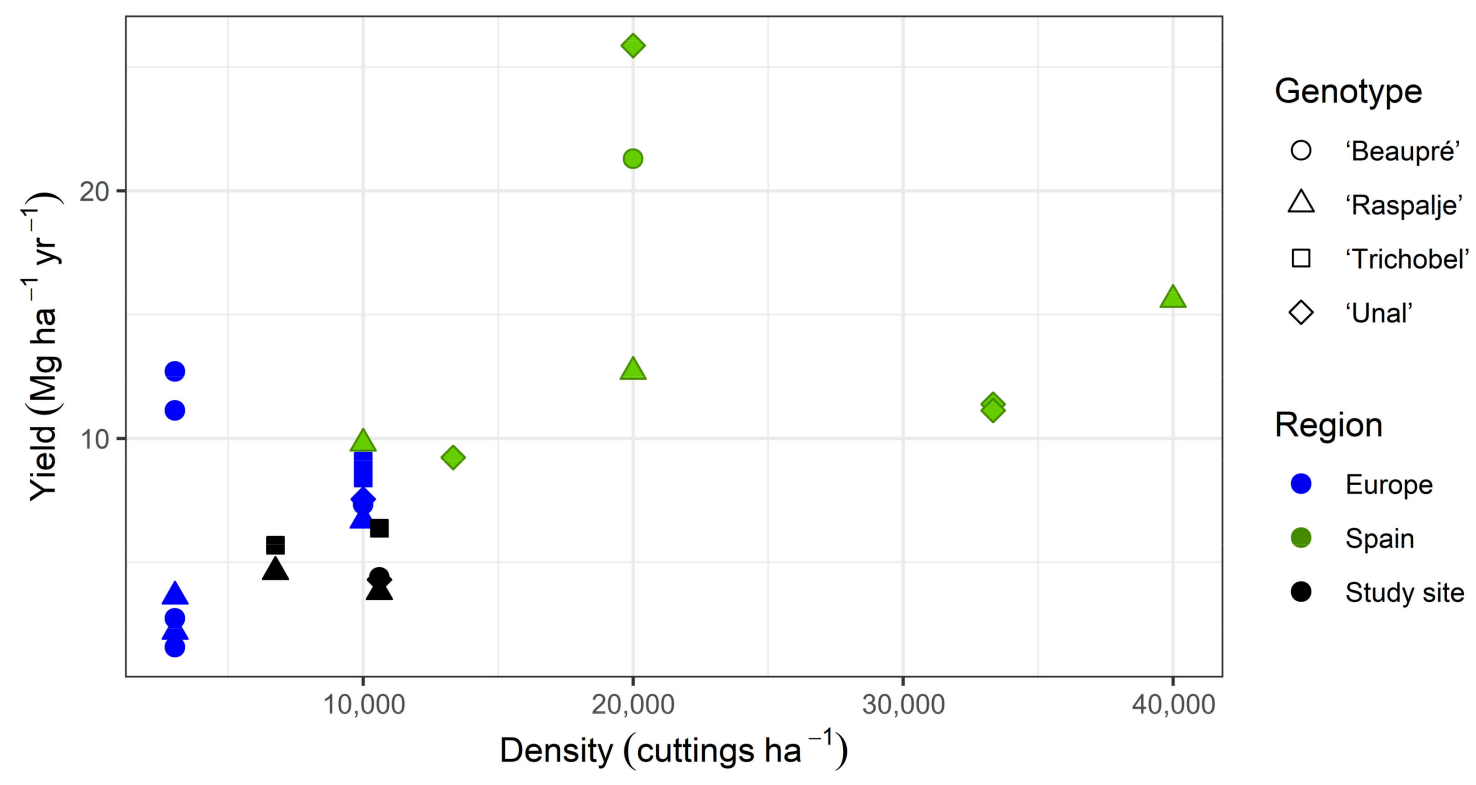

Figure 2. Comparison of yield-density relationship for the most productive clones in the present study and the values cited for these clones in other zones of Spain and Europe gathered in Oliveira, et al. [1], which correspond to the following references showing only plantations between 3 and 4 years old [22-32]. Non-irrigated plantations are represented in dark colors, while irrigated plantations are represented in light colors.

Yield clearly increased with planting density, at least up to the limit of 20,000 cuttings ha ${ }^{-1}$ (Figure 2). In the present case, production only increased with density in the Trichobel clone, but not in the Raspalje clone. Trichobel was the most productive clone in both study sites, yielding $6.37 \mathrm{Mg} \mathrm{ha}^{-1}$ year $^{-1}$ in the trial with the highest tree density and $5.69 \mathrm{Mg} \mathrm{ha}^{-1}$ year $^{-1}$ in the trial with the lowest tree density. These values are slightly lower than those reported for other European countries, such as Belgium, with a production of 8.4 Mg ha ${ }^{-1}$ year $^{-1}$ [22,23], and the U.K., with a production of $9.08 \mathrm{Mg} \mathrm{ha}^{-1}$ year $^{-1}$ [24]. Raspalje was the second most productive clone $\left(4.62 \mathrm{Mg} \mathrm{ha}^{-1}\right.$ year $\left.^{-1}\right)$, with higher values than reported for acid soils in France, 2.2-3.63 $\mathrm{Mg} \mathrm{ha}^{-1}$ year $^{-1}$ [25], but lower than values cited in other European zones, such as the U.K., for which a yield of $6.69 \mathrm{Mg} \mathrm{ha}^{-1}$ year $^{-1}$ was reported [24] or in irrigated plantations in Spain under Mediterranean conditions, for which a higher production of between 9.8 and $15.6 \mathrm{Mg} \mathrm{ha}^{-1}$ year ${ }^{-1}$ has been reported [26].

The size of the experimental trial plots is an important source of variability in predicting biomass yield. Extrapolation of small plots to general yields is known to produce large overestimates [33]. However, in this study, the experimental units are probably large enough to prevent such bias, particularly in trial $2\left(225 \mathrm{~m}^{2}\right)$. The average size of the experimental units for all studies cited in Figure 2 is $126 \mathrm{~m}^{2}$, which is very similar to the size of the experimental units in trial 1 in the present study.

\subsection{Chemical Composition of Ash}

The results of the chemical analysis of the ash samples are shown in Figure 3. The proportion of oxides in the poplar ash followed the order $\mathrm{CaO}>\mathrm{K}_{2} \mathrm{O}>\mathrm{MgO}>>\mathrm{P}_{2} \mathrm{O}_{5}$ $>>\mathrm{SiO}_{2}>\mathrm{Al}_{2} \mathrm{O}_{3}>\mathrm{Na}_{2} \mathrm{O}>\mathrm{Fe}_{2} \mathrm{O}_{5}>>\mathrm{TiO}_{2}$ (where $>>$ denotes an increase of more than twice the concentration). The basal diameter was not a significant covariable for any of the analyzed oxides. The proportion of $\mathrm{CaO}$ ranged from 25.5 to $41 \%$, with a coefficient of variation close to $19 \%$ and with no significant differences between clones. These values are lower than those obtained for ashed samples of Eucalyptus containing bark or pruning remains from urban gardens [9,10]. A study by Girón, et al. [34] reported an average of $55 \% \mathrm{CaO}$ in the fly ash of Eucalyptus bark. In the specific case of SRC poplar plantations, Fernández, et al. [35] reported slightly higher values for irrigated and fertilized plantations 
under Mediterranean conditions (33-43\%). A study by Rodrigues and Nunes [36] also reported higher percentages of $\mathrm{CaO}$ in ash generated from poplar biomass $(48.6 \%)$.

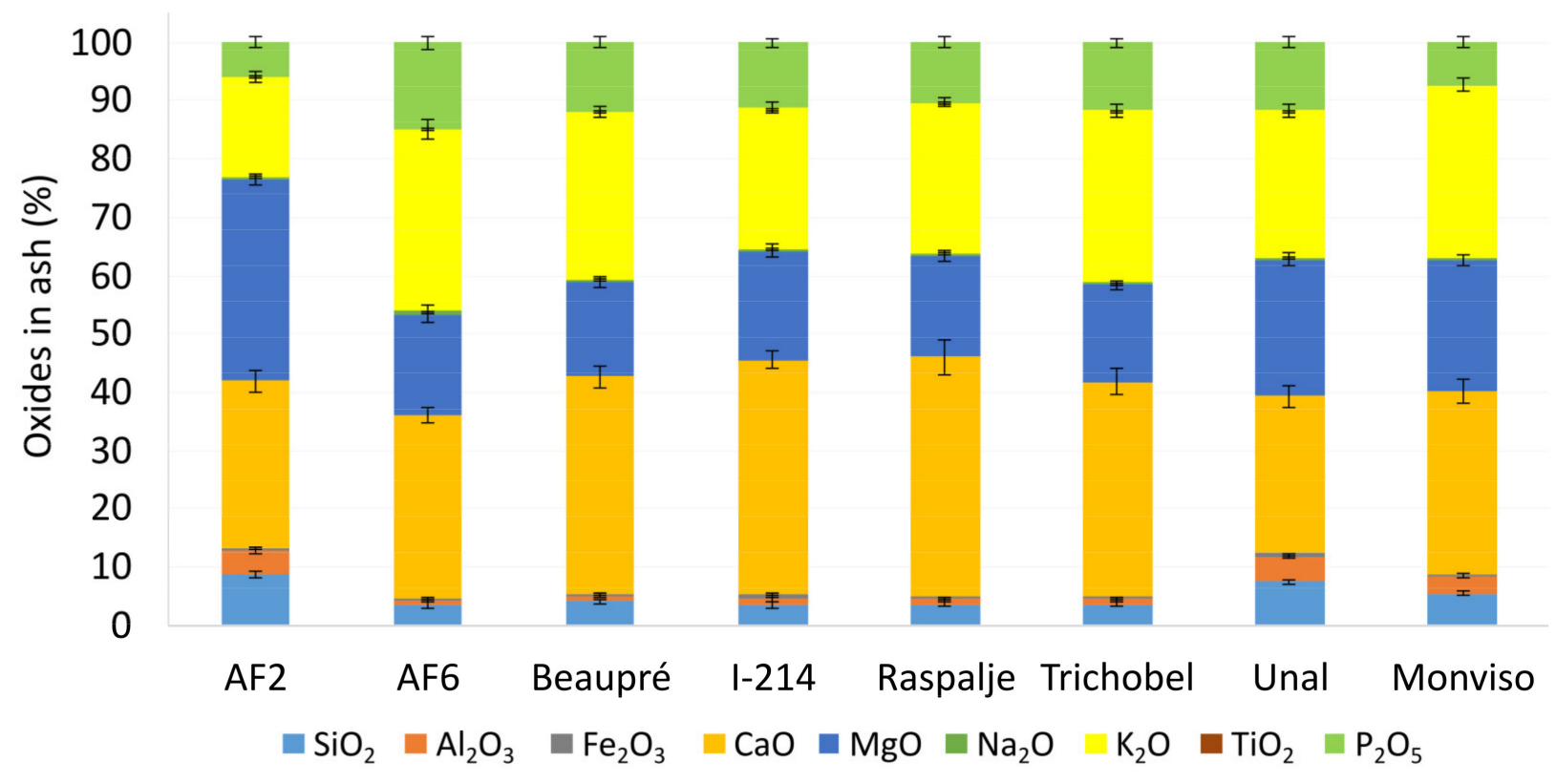

Figure 3. Chemical composition of ash samples by percentage. Errors bars represent \pm standard errors.

The $\mathrm{K}_{2} \mathrm{O}$ content ranged widely, from 16.4 to $36.4 \%$, with significant differences between clones. These values indicate that different clones can have low levels similar to those reported for poplar chips by Vega-Nieva, et al. [8] or high levels very close to those reported for high alkali biomass, such as pinecone chips or olive stones, which showed a moderate tendency for slagging [8]. The study by Fernández, et al. [35] reported levels of $14 \%-17 \%$ for SRC poplar biomass ash. A high $\mathrm{K}_{2} \mathrm{O}$ content in biomass can decrease the ash melting temperature [37]. Samples simultaneously containing high proportions of $\mathrm{K}_{2} \mathrm{O}$ and $\mathrm{SiO}_{2}$ derived from mixtures or contamination tend to undergo hard slagging [8].

The $\mathrm{MgO}$ content ranged from 16.2 to $33.3 \%$, with a coefficient of variation of 15.3. Significant differences between clones were observed, with Monviso, Unal, and AF2 having higher $\mathrm{MgO}$ contents than the others. The proportions determined in the present study are higher than those corresponding to Populus chips used as biofuels [10].

The $\mathrm{P}_{2} \mathrm{O}_{5}$ contents ranged from 5.6 to $17.6 \%$, reaching higher values than those observed in other plantations under Mediterranean conditions, for which values around 5.8 and $6.5 \%$ were reported [35]. The formation of alkali sulfates with low melting temperatures is prevented in biofuels containing sufficient available $\mathrm{Ca}$ to form stable calcium phosphates with available $P$ [36].

The $\mathrm{SiO}_{2}$ content ranged from 2.0 to $8.4 \%$, well below the minimum $25 \% \mathrm{SiO}_{2}$ threshold levels proposed by Öhman, et al. [38] as a risk for slagging. These values are representative of the low intrinsic contents of $\mathrm{SiO}_{2}$ in woody biomass in the absence of soil contamination derived from SRC harvesting and transport [39]. The low intrinsic content of $\mathrm{SiO}_{2}$ in poplar ash has been well established in the literature: 2.7-3.7 [35], 2.3 [36], or 5.9 [40]. Previous studies have pointed out differences between poplar clones and broom in relation to $\mathrm{SiO}_{2}$ content, which influences slag viscosity and deposition levels [36].

The contents of $\mathrm{Al}_{2} \mathrm{O}_{3}$ (average $2.1 \%$ ), $\mathrm{Fe}_{2} \mathrm{O}_{3}$ (average $0.4 \%$ ), $\mathrm{Na}_{2} \mathrm{O}$ (average $0.4 \%$ ), and $\mathrm{TiO}_{2}$ (average $0.02 \%$ ) were minimal and did not differ significantly between clones. These values are similar to those reported by Fernández, et al. [35], Rodrigues and Nunes [36] and Jenkins, et al. [40], with the exception of $\mathrm{Al}_{2} \mathrm{O}_{3}$, which was higher in the present study than in previous studies (0.31 to $0.97 \%$ ). 
The percentage of oxides in the ash is consistent with the chemical composition of biomass. Figure 4 shows the amount of ash forming elements on a mole of element per energy unit of fuel dry matter basis. $\mathrm{K}$ and $\mathrm{Ca}$ are the most abundant elements, with average values slightly below $2 \mathrm{~mol} \mathrm{GJ}^{-1}$. Direct comparison with the poplar biomass analyzed by Díaz-Ramírez, et al. [41] shows that the concentrations determined in the present study are much lower. Comparison of this composition and that of the ash shows that almost all of the $\mathrm{Cl}$ and $\mathrm{S}$ were released through combustion and that $\mathrm{K}$ was only partially $(7 \%)$ released. The other components remained in the ash in the form of oxides.

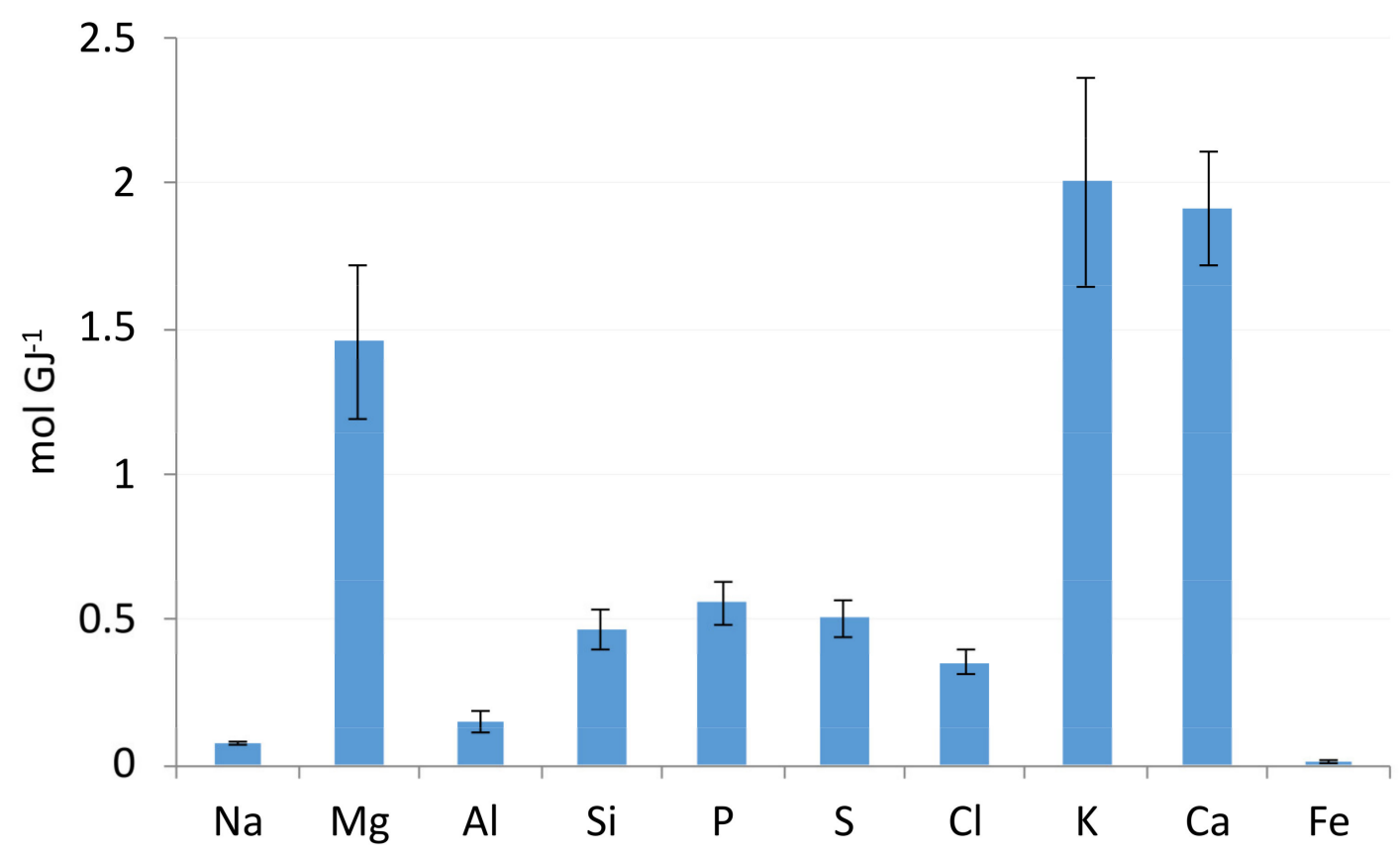

Figure 4. Proportion of main ash-forming elements in the fuel samples and the corresponding standard errors. Amount of ash-forming elements is given on a mole of element per energy unit of fuel dry matter $\left(\mathrm{mol} \mathrm{GJ}^{-1}\right)$ relative to the HHV.

\subsection{Slagging Risk Indeces and Observed Slagging}

The results obtained for the slagging risk indices and actual slagging process show a low level of sintering in the poplar biomass, as reported in Table 4. None of the used indices to evaluate the risk show a high tendency for sintering, although most samples show intermediate values of risk for two the indices related to the alkali content of the ash.

Table 4. Slagging indices calculated on the basis of ash composition at $550{ }^{\circ} \mathrm{C}$.

\begin{tabular}{cccc}
\hline Slagging Index & Average (Sd) & Range & Sintering Level \\
\hline $\mathrm{B}$ & $0.829(0.034)$ & $0.764-0.893$ & $>0.7$ (low risk) \\
$\mathrm{A}\left(\mathrm{kg} \mathrm{GJ}^{-1}\right)$ & $0.196(0.041)$ & $0.102-0.306$ & $72 \%$ medium risk $(\mathrm{A}>0.17), 28 \%$ \\
& & low risk $(\mathrm{A}<0.17)$ \\
$\mathrm{NaK} / \mathrm{B}$ & $0.339(0.051)$ & $0.216-0.442$ & $74 \%$ medium risk $(\mathrm{NaK} / \mathrm{B}>0.3)$, \\
$\mathrm{SiP} / \mathrm{CaMg}$ & $0.290(0.077)$ & $0.138-0.441$ & $26 \%$ low risk \\
$\mathrm{BioSlag}(\%)$ & $0.89(1.46)$ & $0-6.5$ & $<1$ (low risk) \\
$\mathrm{HI}$ & $0.044(0.091)$ & $0-0.4$ & $<0.7$ (low slagging) \\
\hline
\end{tabular}

All the of the slagging risk indices differed significantly in relation to each clone, with no covariate effects derived from the different basal diameters. Clones such as AF6 and Unal yielded higher values than the other clones, indicating a comparatively lower content 
of alkaline earth oxides in the ash than the alkali oxides or the $\mathrm{SiO}_{2}+\mathrm{P}_{2} \mathrm{O}_{5}$ content. The comparison is shown in Figure 5.

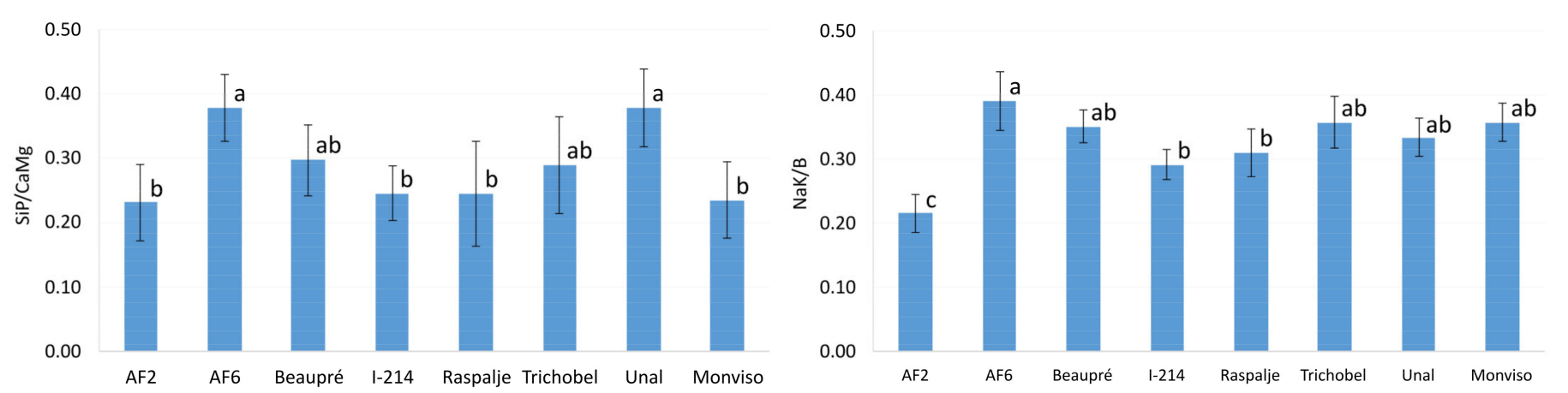

Figure 5. Mean and standard errors of the SiP/CaMg and the NaK/B indices obtained from ash of the eight clones under study. Different letters denote significant differences (Tukey test).

Significant differences between clones were observed in regard to the BioSlag test $(p<0.001)$, with clones AF6 and Unal showing a higher level of slagging than the other clones, although the percentages were still very low. The same was observed for the hardness index; in this case, four clones produced significantly higher values, but still had a low slagging level (Figure 6). The intra-clone variability was very high. Notably, the clones previously selected for their ability to grow in these acid soils also ranked among the best in terms of ash behavior (Trichobel and Raspalje). This is consistent with the previous results of Eimil-Fraga, et al. [4], showing that poplar clones in the balsam poplar group or with a parent in this group seemed to be of much higher quality than the black poplar clones, probably because they can grow in sites with acid soils rich in organic matter but that are relatively poor in mineral fertility.
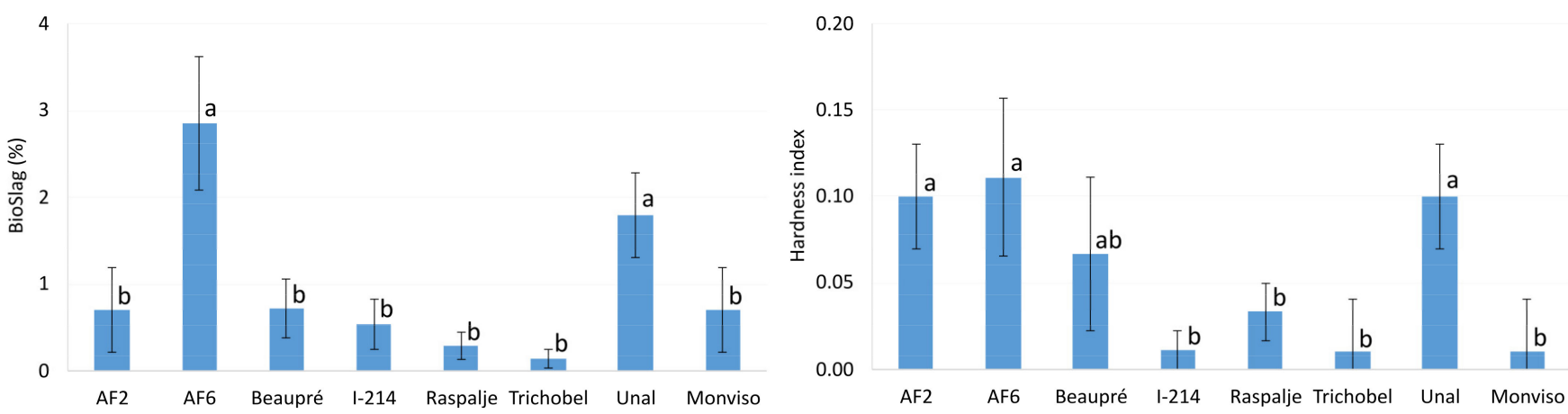

Figure 6. Mean values and standard errors for the BioSlag test (\%) and the hardness index for sintered particles from the eight clones under study. Different letters denote significant differences (Tukey test).

The actual sintering level measured by the BioSlag test and the risk indices were weakly, although significantly, related. The linear coefficient of correlation between BioSlag and $\mathrm{SiP} / \mathrm{CaMg}$ was $0.56(p<0.05)$, and the corresponding correlation between BioSlag and $\mathrm{NaK} / \mathrm{B}$ was $0.40(p<0.05)$. A scatter plot for the risk index found to be most closely related to the actual sintering is shown in Figure 7 . Although the observed values were much lower than those considered to be risky ( $\mathrm{SiP} / \mathrm{CaMg}<1$, Vega-Nieva, et al. [8]), a tendency for the sintering to increase with the $\mathrm{SiP} / \mathrm{CaMg}$ was observed. 


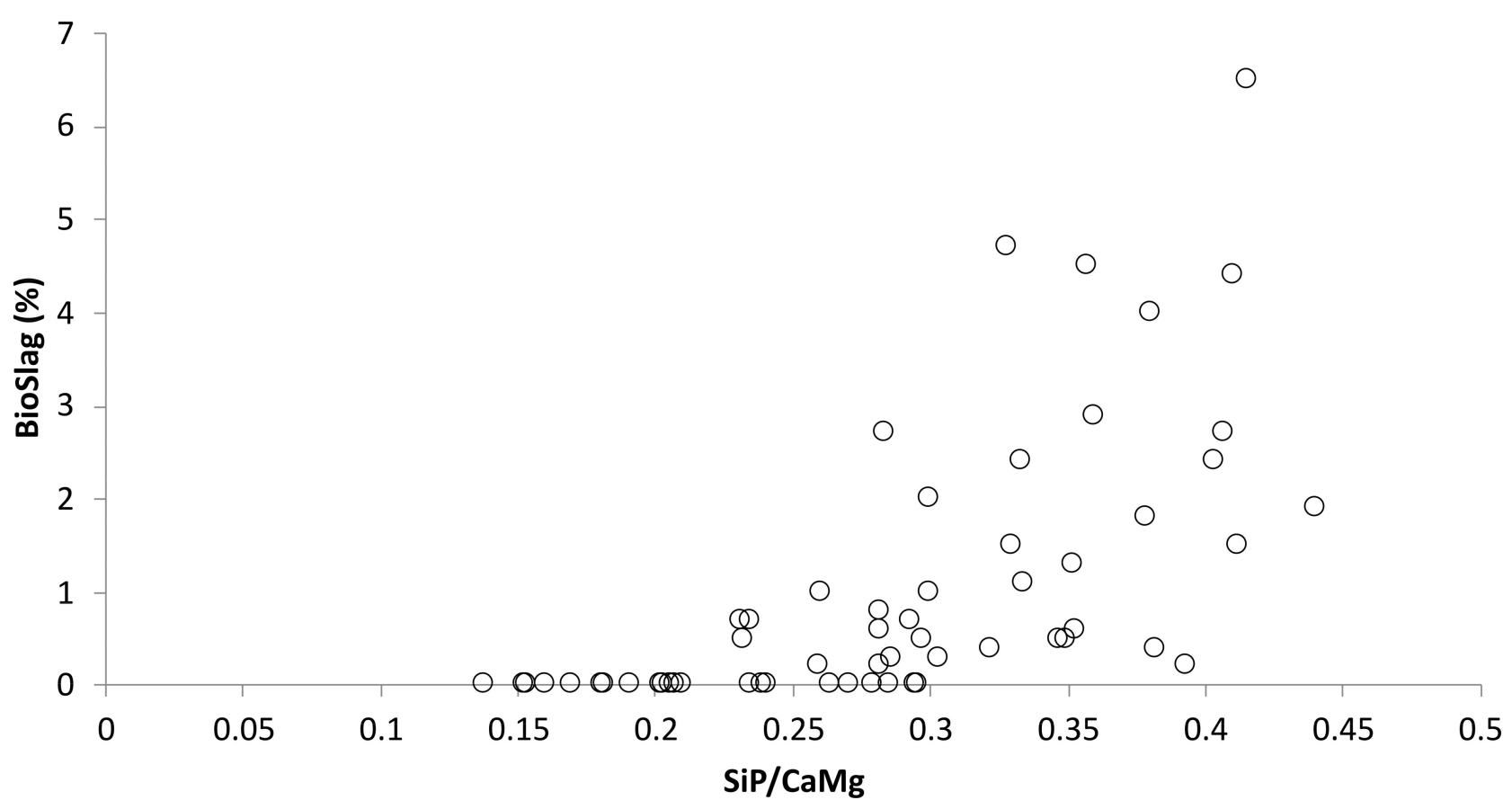

Figure 7. Scatter plot of the SiP/CaMg index and the slagging evaluated by the BioSlag test.

A low tendency for deposition was also reported by Rodrigues and Nunes [36] for poplar clones, except for clones AF2 and AF8, which were prone to slagging induced by silicate melting. These authors also studied the balsam poplar clones Bakam and Skado and did not find any differences in ash composition or slagging trends relative to the other clones that were tested.

The study findings confirm that woody biomass produced from poplar does not undergo severe sintering during the combustion process [42]. This has been shown to be related to the high melting temperature of the ash and to the presence of large amounts of refractive compounds in the ash [43]. Nonetheless, the present findings show that $\mathrm{K} / \mathrm{Ca}$ ratios may be higher than previously reported for poplar [44]. Special care should be taken to prevent contamination with sand or clays to prevent the formation of potassium silicates.

\section{Conclusions}

Growing site-undemanding balsam poplar clones for biomass production in acid soils can yield reasonable levels of biomass with no need for irrigation when the climatic conditions are suitable. The selection of clones adapted to these conditions is necessary to reduce initial mortality and improve growth. The Trichobel clone yielded the best results in both trials. The biomass generated under these conditions has a lower content of alkaline earth components than other poplar biomass, so the ash is less prone to sintering. The actual sintering level was found to be very low, and the sintering risk that was the most closely related to actual sintering was associated with $\mathrm{SiP} / \mathrm{CaMg}$.

Author Contributions: C.E.-F. and N.O. contributed equally to this paper. Conceptualization, C.E.-F. and R.R.-S.; Data Curation, C.E.-F.; Formal Analysis, C.E.-F., N.O., L.O.-T., J.L.R.-S. and R.R.-S.; Methodology, L.O.-T., J.L.R.-S. and R.R.-S.; Investigation, R.R.-S.; Resources, C.E.-F.; WritingOriginal Draft Preparation, C.E.-F., N.O. and R.R.-S.; Writing-Review \& Editing, N.O. and R.R.-S.; Visualization, N.O.; Supervision, R.R.-S.; Project Administration, R.R.-S.; Funding Acquisition, R.R.-S. All authors have read and agreed to the publisher version of the manuscript.

Funding: This research was financially supported by project RTA2017-00015-C02-02, Spanish Ministry of Economy and Competitivity.

Institutional Review Board Statement: Not applicable. 
Informed Consent Statement: Not applicable.

Data Availability Statement: Not applicable.

Acknowledgments: The authors wish to thank Christine Francis for the language editing.

Conflicts of Interest: The authors declare no conflict of interest.

\section{References}

1. Oliveira, N.; Pérez-Cruzado, C.; Cañellas, I.; Rodríguez-Soalleiro, R.; Sixto, H. Poplar Short Rotation Coppice Plantations under Mediterranean Conditions: The Case of Spain. Forests 2020, 11, 1352. [CrossRef]

2. Cai, J.; He, Y.; Yu, X.; Banks, S.W.; Yang, Y.; Zhang, X.; Yu, Y.; Liu, R.; Bridgwater, A.V. Review of physicochemical properties and analytical characterization of lignocellulosic biomass. Renew. Sustain. Energy Rev. 2017, 76, 309-322. [CrossRef]

3. McKendry, P. Energy production from biomass (part 1): Overview of biomass. Bioresour. Technol. 2002, 83, 37-46. [CrossRef]

4. Eimil-Fraga, C.; Proupín-Castiñeiras, X.; Rodríguez-Añón, J.A.; Rodríguez-Soalleiro, R. Effects of Shoot Size and Genotype on Energy Properties of Poplar Biomass in Short Rotation Crops. Energies 2019, 12, 2051. [CrossRef]

5. Garcia-Maraver, A.; Mata-Sanchez, J.; Carpio, M.; Perez-Jimenez, J.A. Critical review of predictive coefficients for biomass ash deposition tendency. J. Energy Inst. 2017, 90, 214-228. [CrossRef]

6. Feldmeier, S.; Wopienka, E.; Schwarz, M.; Bardar, R.M. Innovative flexible grate solutions for future biomass combustion appliances. In Proceedings of the 25th EUBCE European Biomass Conference and Exhibition Proceedings, ETA-Florence Renewable Energies, Stockholm, Sweden, 12-15 June 2017; pp. 566-567.

7. Monedero, E.; Hernández, J.J.; Cañellas, I.; Otero, J.M.; Sixto, H. Thermochemical and physical evaluation of poplar genotypes as short rotation forestry crops for energy use. Energy Convers. Manag. 2016, 129, 131-139. [CrossRef]

8. Vega-Nieva, D.J.; Ortiz Torres, L.; Míguez Tabares, J.L.; Morán, J. Measuring and predicting the slagging of woody and herbaceous Mediterranean biomass fuels on a domestic pellet boiler. Energy Fuels 2016, 30, 1085-1095. [CrossRef]

9. Rodríguez, J.L.; Álvarez, X.; Valero, E.; Ortiz, L.; de la Torre-Rodríguez, N.; Acuña-Alonso, C. Design of solid biofuels blends to minimize the risk of sintering in biomass boilers. J. Energy Inst. 2020, 93, 2409-2414. [CrossRef]

10. Rodríguez, J.L.; Álvarez, X.; Valero, E.; Ortiz, L.; de la Torre-Rodríguez, N.; Acuña-Alonso, C. Influence of ashes in the use of forest biomass as source of energy. Fuel 2021, 283, 119256. [CrossRef]

11. Gilbe, C.; Ohman, M.; Lindström, E.; Boström, D.; Backman, R.; Samuelsson, R.; Burvall, J. Slagging characteristics during residential combustion of biomass pellets. Energy Fuels 2008, 22, 3536-3543. [CrossRef]

12. UNE-EN ISO 18122. Solid Biofuels. Determination of Ash Content; AENOR: Madrid, Spain, 2016; p. 14.

13. UNE-EN ISO 16967. Solid Biofuels. Determination of Major Elements Al, Ca, Fe, Mg, P, K, Si, Na and T; AENOR: Madrid, Spain, 2015; p. 20.

14. UNE-EN ISO 16994. Solid Biofuels. Determination of Total Content of Sulfur and Chlorine; AENOR: Madrid, Spain, $2017 ;$ p. 18.

15. Feldmeier, S.; Wopienka, E.; Schwarz, M.; Schön, C.; Pfeifer, C. Applicability of fuel indexes for small-scale biomass combustion technologies, part 1: Slag formation. Energy Fuels 2019, 33, 10969-10977. [CrossRef]

16. Bryers, R.W. Fireside slagging, fouling, and high-temperature corrosion of heat-transfer surface due to impurities in steam-raising fuels. Prog. Energy Combust. Sci. 1996, 22, 29-120. [CrossRef]

17. Miles, T.R.; Miles, T.R., Jr.; Baxter, L.L.; Bryers, R.W.; Jenkins, B.M.; Oden, L.L. Boiler deposits from firing biomass fuels. Biomass Bioenergy 1996, 10, 125-138. [CrossRef]

18. R Core Team. R: A language and environment for statistical computing; R Foundation for Statistical Computing: Viena, Austria, 2020.

19. Pérez-Cruzado, C.; Sanchez-Ron, D.; Rodríguez-Soalleiro, R.; Hernández, M.; Sánchez-Martín, M.; Cañellas, I.; Sixto, H. Biomass production assessment from Populus spp. short-rotation irrigated crops in Spain. Glob. Chang. Biol. Bioenergy 2013, 6, 312-326. [CrossRef]

20. San Miguel, G.; Corona, B.; Ruiz, D.; Landholm, D.; Laina, R.; Tolosana, E.; Sixto, H.; Cañellas, I. Environmental, energy and economic analysis of a biomass supply chain based on a poplar short rotation coppice in Spain. J. Clean. Prod. 2015, 94, 93-101. [CrossRef]

21. Gasol, C.M.; Gabarrell, X.; Anton, A.; Rigola, M.; Carrasco, J.; Ciria, P.; Rieradevall, J. LCA of poplar bioenergy system compared with Brassica carinata energy crop and natural gas in regional scenario. Biomass Bioenergy 2009, 33, 119-129. [CrossRef]

22. Laureysens, I.; Deraedt, W.; Indeherberge, T.; Ceulemans, R. Population dynamics in a 6-year old coppice culture of poplar. I. Clonal differences in stool mortality, shoot dynamics and shoot diameter distribution in relation to biomass production. Biomass Bioenergy 2003, 24, 81-95. [CrossRef]

23. Laureysens, I.; Pellis, A.; Willems, J.; Ceulemans, R. Growth and production of a short rotation coppice culture of poplar. III. Second rotation results. Biomass Bioenergy 2005, 29, 10-21. [CrossRef]

24. Aylott, M.J.; Casella, E.; Tubby, I.; Street, N.R.; Smith, P.; Taylor, G. Yield and spatial supply of bioenergy poplar and willow short-rotation coppice in the UK. New Phytol. 2008, 178, 358-370. [CrossRef]

25. Berthelot, A. Mélange de clones en taillis à courtes rotations de peuplier: Influence sur la productivité et l'homogénéité des produits récoltés. Can. J. For. Res. 2001, 31, 1116-1126. [CrossRef] 
26. Ciria, M.; González, E.; Carrasco, J. The effect of fertilization and planting density on biomass productivity of poplar harvested after three-years rotation. In Proceedings of the 12th European Conference on Biomass for Energy, Industry and Climate Protection, Amsterdam, The Netherlands, 17-21 June 2002; pp. 283-286.

27. Ciria, P. Efecto del Turno de corta y de la Densidad de Plantación Sobre la Productividad de Diversos Clones de Chopo en Condiciones de Corta Rotación; Universidad Politécnica de Madrid: Madrid, Spain, 1999.

28. Ibarra, D.; Eugenio, M.E.; Cañellas, I.; Sixto, H.; Martín-Sampedro, R. Potential of different poplar clones for sugar production. Wood Sci. Technol. 2017, 51, 669-684. [CrossRef]

29. Martín-Sampedro, R.; Eugenio, M.E.; Cañellas, I.; Sixto, H.; Ibarra, D. Characterization of different poplar clones for sugar production. In Proceedings of the 1st International Workshop on Biorefinery of Lignocellulosic Materials, Cordoba, Spain, 9-12 June 2015.

30. Sixto, H.; Rueda, J. Evaluación de genotipos para la producción de biomasa con fines energéticos en la Comunidad de Castilla y León. In Proceedings of the $5^{\circ}$ Congresos Forestales, Ávila, Spain, 21-25 September 2009.

31. Sixto, H.; Gil, P.; Ciria, P.; Camps, F.; Sánchez, M.; Cañellas, I.; Voltas, J. Performance of hybrid poplar clones in short rotation coppice in Mediterranean environments: Analysis of genotypic stability. GCB Bioenergy 2014, 6, 661-671. [CrossRef]

32. Valbuena-Castro, J.; Oliveira, N.; Rodríguez-Soalleiro, R.; Sixto, H.; Cañellas, I. Biomass productivity assessment at a clonal forest of Populus spp. at Valtierra (Navarra, Spain). In Proceedings of the Xth Young Researchers Meeting on Conservation and Sustainable Use of Forest Systems, Valsaín, Spain, 25-26 January 2016.

33. Hansen, E.A. Poplar woody biomass yields: A look to the future. Biomass Bioenergy 1991, 1, 1-7. [CrossRef]

34. Girón, R.; Suárez-Ruiz, I.; Ruiz, B.; Fuente, E.; Gil, R. Fly ash from the combustion of forest biomass (Eucalyptus globulus bark): Composition and physicochemical properties. Energy Fuels 2012, 26, 1540-1556. [CrossRef]

35. Fernández, M.J.; Barro, R.; Pérez, J.; Losada, J.; Ciria, P. Influence of the agricultural management practices on the yield and quality of poplar biomass (a 9-year study). Biomass Bioenergy 2016, 93, 87-96. [CrossRef]

36. Rodrigues, A.; Nunes, L. Evaluation of ash composition and deposition tendencies of biomasses and torrefied products from woody and shrubby feedstocks: SRC poplar clones and common broom. Fuel 2020, 269, 117454. [CrossRef]

37. Arranz, J.; Miranda, M.; Montero, I.; Sepúlveda, F.; Rojas, C. Characterization and combustion behaviour of commercial and experimental wood pellets in South West Europe. Fuel 2015, 142, 199-207. [CrossRef]

38. Öhman, M.; Nordin, A.; Hedman, H.; Jirjis, R. Reasons for slagging during stemwood pellet combustion and some measures for prevention. Biomass Bioenergy 2004, 27, 597-605. [CrossRef]

39. Werkelin, J.; Skrifvars, B.-J.; Hupa, M. Ash-forming elements in four Scandinavian wood species. Part 1: Summer harvest. Biomass Bioenergy 2005, 29, 451-466.

40. Jenkins, B.; Baxter, L.; Miles, T., Jr.; Miles, T. Combustion properties of biomass. Fuel Process. Technol. 1998, 54, 17-46. [CrossRef]

41. Díaz-Ramírez, M.; Frandsen, F.J.; Glarborg, P.; Sebastián, F.; Royo, J. Partitioning of K, Cl, S and P during combustion of poplar and brassica energy crops. Fuel 2014, 134, 209-219. [CrossRef]

42. Du, S.; Yang, H.; Qian, K.; Wang, X.; Chen, H. Fusion and transformation properties of the inorganic components in biomass ash. Fuel 2014, 117, 1281-1287. [CrossRef]

43. Zhu, Y.; Hu, J.; Yang, W.; Zhang, W.; Zeng, K.; Yang, H.; Du, S.; Chen, H. Ash fusion characteristics and transformation behaviors during bamboo combustion in comparison with straw and poplar. Energy Fuels 2018, 32, 5244-5251. [CrossRef]

44. Boström, D.; Skoglund, N.; Grimm, A.; Boman, C.; Ohman, M.; Brostrom, M.; Backman, R. Ash transformation chemistry during combustion of biomass. Energy Fuels 2012, 26, 85-93. [CrossRef] 